\title{
Analysis and Consideration of Construction Project Management Simulation Training Course
}

\author{
Yunxia Jiang* \\ Shanghai Sanda Institute \\ Shanghai, China \\ april2002@126.com
}

\begin{abstract}
In order to improve the practical teaching of Construction Project Management course and improve the practical operation and comprehensive ability of students, we do some research about Construction Project Management Simulation Training course in this paper. Through literature research methods and interviews with some teachers and students, the application status of the sand table simulation in the practical teaching of Construction Project Management course is introduced and the characteristics and the problems of Construction Project Management Simulation Training course are analyzed in this paper. On the basis of the analysis, some suggestions which may improve the teaching of Construction Project Management Simulation Training course are put forward. It is hoped that these suggestions can provide some reference for the practice teaching reform of Construction Project Management course.
\end{abstract}

Keywords-construction; project; management; simulation; course

\section{INTRODUCTION}

Construction Project Management course is one of the core courses of Engineering Management major. It has the important characteristics of paying attention to the combination of theory and practice. The mastery of construction project management is the embodiment of the students' important professional ability. At present, the teaching of Construction Project Management course in many colleges is the mode which is mainly based on theoretical explanation and case study. Its learning effect is far from the actual experience requirements of the employers for graduates of Engineering Management major. The introduction of the appropriate sand table simulation practice means can make up for the deficiencies in the practice of Construction Project Management course. But this means still need to be further improved. In this paper, we will try to analyze the application status and problems of the sand table simulation in the practical teaching of Construction Project Management course by using the methods of literature research and investigation and interview, and we will try to put forward some experience and suggestions through analysis and research, so as to provide some reference for the reform of practical teaching of Construction Project Management course.

\section{INTRODUCTION OF SAND TABLE SIMULATION}

\section{A. Introduction of Sand Table}

Sand table was originally a field command tool in military warfare. It can visually display the topography of the occupied area, and indicate the composition of enemy and ours positions, the deployment of troops and the disposition of weapons [1]. Therefore, through the physical model of sand table, military commanders can intuitively understand the whole battlefield without visiting the scene, and then study the shape, enemy situation, combat plan, organize coordinated action, implement tactical drills and so on, so as to strategize and make the best decision [2].

\section{B. Introduction of Sand Table Simulation}

At the end of the 19th century and the beginning of the 20th century, sand tables were mainly used for military training, and they were not used in actual battlefields until World War I[3]. Then sand table simulation is gradually applied to many fields, such as enterprise production, housing exhibition, teaching and scientific research, landscape design, and even urban planning. In recent years, the enterprise management sand table designed for ERP (Enterprise Resource Planning System) has been widely used in many colleges. But there are not many colleges that use sand table simulation in the teaching of construction project management course. Sand table simulation training in the course of Construction Project Management course can help students master an effective method to deal with the uncertainty of engineering projects, make project decisions scientifically, and better understand the risks of projects, so as to cultivate students' modern project management skills and improve students' project management level[4].

\section{APPLICATION STATUS OF CPMST COURSE}

Construction Project Management Simulation Training course which can be abbreviated as CPMST course in this paper is the sand table simulation training course of Construction Project Management course. The current situation, characteristics and existing problems of Construction Project Management Simulation Training course will be studied and analyzed in this part. 


\section{A. Status Introduction of CPMST Course}

Faced with the development of Engineering Management major and the demand for practical teaching in colleges, there are many sand table simulation training courses for construction project management which are developed by some enterprises, such as GLODON Company Limited, JIECL Company Limited, etc.

1) Definition of Construction Project Management Simulation Training: Construction project management simulation training is based on the perspective of the construction unit. It simulates the whole process of the construction project from the tender to the completion and acceptance of the project. In this process, students will carry out practical activities around the core issues of schedule planning, business operation, costs planning and risk management in the construction.

Construction Project Management Simulation Training course can enable students to play the role of simulation in the classroom. Through the simulation environment, simulation coins, simulation resources and so on, they can experience a simulated construction project, and experience the whole process of construction project management, practice project management theory and master project management tools.

2) Objectives of Course: The following goals and values can be achieved by offering Construction Project Management Simulation Training course.

- With the help of the simulated construction project management environment, students will be familiar with the main contents of the whole process of construction project management.

- Create experiential learning, experience project roles and processes, and understand each other among positions.

- Master the balance of project progress, cost and quality, grasp the project life cycle, and cultivate the awareness and ability of project team members to create maximum business value with limited resources.

- Understand the nature of project management and key control points of project management. Familiar with the relationship between profit and cost, and master the process of project management.

- Balance the relationship between local and overall benefits, and cultivate students' competitive consciousness and team cooperation ability.

3) Practical training content: In the Project Management Simulation Training teaching by GLODON Company Limited, teachers can adopt the form of drawing lots or randomly grouping, and each 4-6 people can be divided into a group to form a project management team. Students can simulate different roles and responsibilities in the project. Students can experience the whole process of project implementation and understand the essence of project management. The training contents include making construction organization schedule, optimizing construction scheme, production management, financial management, team cooperation and communication, etc.[5].In the Project Management Simulation Training developed by JIECL Company Limited, the training content covers six modules, including project objective selection, project contract management and resource planning, project schedule management, project communication and team cooperation, project cost and benefit management, project quality and risk management. In conclusion, through this project management simulation training, students can have a deeper understanding of the project management course. And students can link related disciplines and related curriculum knowledge.

1) Methods and Standards of Assessment: The evaluation of training results is the key and difficult point of the whole project management simulation teaching. The score is mainly based on the score of course software analysis. The final assessment results of the students include team assessment and individual assessment of the students, together with their usual performance [6]. Different schools have different assessment methods according to the specific reference scoring standards. Usually, the final scores of the students' transcripts are entered in the form of qualified and unqualified [7].

\section{B. Analysis of CPMST Course's Characteristics}

Through comprehensive analysis of teachers' and students' understanding of the Construction Project Management Simulation Training course and with relevant literature research, several characteristics of Construction Project Management Simulation Training course are obtained.

1) Innovation of Teaching Method: The introduction of sand table as a teaching tool in CPMST teaching can make teaching methods more diversified. It can stimulate students' interest in learning, and it can enable students to better grasp the theoretical knowledge and practical operation of project management.

a) Project-based teaching method:In the process of teaching, project-based teaching is integrated into the curriculum with the help of project management sand table. Students are divided into groups of 5-6 people. Each group is equivalent to a project department and each person plays different roles, and the roles can be exchanged in the training process. It mainly trains students to master the necessary knowledge of project management [1].

b) Experiential teaching method:In teaching method, students' participation and experiential learning are emphasized. CPMST course provides a new teaching idea, which attracts students to the classroom in the form of a similar game, and students become the main body of teaching. In the experiential teaching, students actively think in combination with specific problems, which greatly stimulates the enthusiasm of learning and turns passive learning into active learning [8].

2) Focus on Integration of Professional Knowledge: CPMST course includes financing, cost control, schedule control, safety management, contract management and 
information management of construction project, which reflects a kind of operation condition in the implementation stage of construction project. The course provides a platform for students to improve their knowledge structure, which can cultivate their ability to apply relevant knowledge to solve practical problems. And the course can help them understand the internal links between various knowledge points and can help them understand the whole knowledge system of project management .

3) Cultivation of Comprehensive Ability: In the course, students need to make simulated decisions and they need to apply the theoretical knowledge of many previous disciplines to the process of project management. It is possible to train students' practical and innovative abilities to analyze and solve problems on the basis of comprehensive application of the knowledge they have learned. And in the course, students need to think systematically from the perspective of engineering decision-makers, which may cultivate students' engineering consciousness and lay a solid knowledge foundation for their future work[9].

4) Focus on the Training of Team Cooperation Ability:CPMST course is a course that emphasizes interaction among students. Students form project management teams and simulate different roles, assume different responsibilities, and jointly implement the project. In the process of the project, we will encounter various problems[10]. Therefore, it is necessary for project members to cooperate with each other, to solve problems and to achieve project objectives through communication and teamwork.CPMST course can not only train students' communication ability, but also make them learn team spirit in the process of disagreement to unity.

\section{Problems of CPMST Course}

1) Training links: The following is about the problems of CPMST course in the training links.

a) The training hours:The training hours are insufficient and the sand table training room is not fully utilized. CPMST course is different from the previous classroom teaching. In terms of time, it takes a whole period of time. Generally, a case needs at least four lessons at the beginning, and it often takes a whole day to practice. Because of the time factor, many schools only arrange one or two days to study after the end of the project management course. Maybe it's over before students realize its usefulness.

b) The assessment criteria: The assessment criteria are not perfect. Because CPMST course is a relatively new course, many schools are still in the trial stage, and have not yet formed a systematic curriculum standard. Therefore, after the students' training, teachers make a simple oral comment on the performance of each group of students. Most of the students are assessed by teams or individuals in a qualified and unqualified way [6].

2) On the content of practical training: The following is about the problems of CPMST course on the content of practical training.
- The whole process management simulation ability of construction project management needs to be improved. At present, some software companies still use two independent systems to simulate construction project management and bidding management. In addition, the corresponding simulation system has not been formed for the project management in the pre-design and design stages. Especially how to integrate the simulation capability of the whole process management of the project needs to be further strengthened. Therefore, it needs to upgrade and supplement the comprehensiveness of project management simulation.

- The simulated project is simple now. In some simulation projects of software companies, in order to speed up the process of project simulation, some very simple projects are designed, such as a gate, a simple bridge and so on. This makes it difficult for students to have a thorough and detailed understanding of complex project management in their future work. Therefore, more typical simulation projects need to be developed. At present, most of the sand table simulation teaching systems can't simulate real projects. The real project cannot be simulated completely.

\section{SUGGESTIONS OF CPMST COURSE}

As a new teaching method and tool, CPMST course plays an active role in improving the teaching quality of construction project management course. In order to promote the implementation of sand table simulation teaching more effectively, and further improve the practical operation and comprehensive ability of students, the following suggestions are summarized, combined with the results of literature research and interviews of some teachers and students.

\section{A. Laboratory construction}

The construction of CPMST course laboratory requires not only sand table teaching aids, but also high hardware environment, such as server, computer, network equipment, projector and multimedia teaching system[4]. At the same time, software should also match the requirements of sand table simulation teaching, such as sand table simulation teaching software, cost software, drawing software, evaluation software and so on. Special attention should be paid to the indepth integration of BIM which is called Building information model technology and project management. In addition, we should strengthen the construction of experimental guidance textbooks, laboratory utilization management system and engineering database. Only when the hardware, software and related materials of the laboratory meet the requirements, we can carry out CPMST teaching smoothly, so as to improve the practical teaching system and improve the teaching quality [7].

\section{B. On the Construction of Teachers' Team}

Implementing sand table simulation teaching puts forward higher requirements for instructors, who not only need have rich professional theoretical basis and practical operation ability, but also need grasp the whole simulation process in an 
all-round way. Therefore, professional teachers can be selected to participate in practical training in enterprises to train and become double-qualified teachers. In addition, teachers can be encouraged to lead students to participate in sand table contests [6]. Through leading the team competition and personally guiding the operation, teachers' practical ability can be strengthened, and the effect of practical teaching can be improved [11].

\section{Improvement of training links}

Firstly, we can increase the training hours in theory course. The use of sand table laboratory is allocated to the daily teaching of project management course. For example, when teachers are explaining the form of project organization, students can use the laboratory to study in groups, so that they can fully appreciate the advantages and disadvantages of various forms of organization. Secondly, we can further improve the sand table training courses, such as the formulation of laboratory task paper and assessment criteria. In addition, we can cooperate with software companies to develop projects cases, and give priority to engineering cases, so that students can access more real engineering examples.

\section{Strengthening students' practice}

Although CPMST teaching can play a certain practical teaching purpose, sand table simulation is different from engineering practice after all. Therefore, in order to enable students to truly participate in the actual project management, it is necessary to strengthen the construction of practice base and organize students to visit the construction site for practice. Strengthening the construction of practice base is also conducive to cooperating with CPMST teaching.

\section{CONCLUSION}

The introduction of sand table simulation teaching realizes the mutual transformation of teaching and learning, and alleviates the problem of weak practice links in Construction Project Management course in colleges. The introduction of sand table simulation teaching makes up for the shortcomings of traditional construction project management teaching. The course can enable students to grasp the professional knowledge of construction project management more profoundly and improve the teaching effect in a limited time. The course is an innovation in the teaching of Engineering Management major.

At present, there are still some shortcomings in the sand table simulation course of construction project management, such as the simulation of the teaching focus in the construction stage and the whole process of construction project management can't be fully simulated, the limited hours of sand table simulation training in schools and the imperfect assessment standards etc. Because of the shortcomings, some suggestions are tentatively put forward based on the results of literature research and interviews in this paper.

Nowadays, the information technology is increasingly updated. The technology of construction project management sand table is also developing and improving and BIM technology is improving in the field of engineering management now. With the development of these technologies, sand table simulation will play an increasingly important role in the teaching reform of Construction Project Management course. So the research on CPMST course is very valuable and necessary.

\section{REFERENCES}

[1] Yanjuan Tang, Yu Jiang, Mingsheng He, Duotian Xia, Jun Yang, Lei Wang, "the application of sand table simulation in practical teaching of engineering project management”, Journal of Shihezi University (Philosophy and Social Sciences Edition), vol. 25, pp. 129-131, 2011, (In Chinese)

[2] Xia Wang, Yaofang Liu, "Application of Sand Table Simulation in Engineering Project Management Course”, Sichuan Building Materials, vol42, pp. 218, Sept. 2016, (In Chinese)

[3] Liu Cheng, "Sand Table Simulation Teaching Practice of Engineering Project Management Based on BIM", Research and Exploration Laboratory, vol.31, pp. 433-437, Oct. 2012, (In Chinese)

[4] Ma Yan, "The Application of Sand Table Simulation in the Teaching of Engineering Project Management”, Journal of Chifeng University (Natural Science Edition), vol.31, pp. 255-256, Jun. 2015, (In Chinese)

[5] Hongtao Li, Xiping Zhang, Xiaofeng Zhou, "Project Management Simulation Training Course”, Chongqing University Press, June 2013. (In Chinese)

[6] Xiaoni Jia, "The First Teaching Reform Exploration about "Engineering Project Management” Based on the Concept of CDIO”, Value Engineering, pp.68-73, 2012, (In Chinese)

[7] Jianwen Huang, Qin Huang, Ting Zhang, Wenjuan Ma, "Process design of sand table simulation in engineering project management based on "sandwich" mode", Journal of architectural education in institutions of higher learning, vol.23, pp. 136-140, 2014, (In Chinese)

[8] Fang Liu, Exploration of Sand Table Experiment Teaching in Engineering Project Management Course, Industrial \& Science Tribune, pp. 185-186, 2016, (In Chinese)

[9] Peng Mao, “Application of sand table in project management teaching”, Journal of architectural education in institutions of higher learning, vol.21, pp. 89-93, 2012, (In Chinese)

[10] Weixing Liu, Xiaoshuang Shao, Youjia Zhang, "Project Management Sand Table Simulation Teaching Reform and Practice”, Science \& Technology Vision, pp. 37-38, 2014, (In Chinese)

[11] Yuan Yao, "the application and analysis of simulation teaching in engineering management major”. Consume Guide, pp. 189, Jan. 2016 (In Chinese) 